Journal of Nuclear Medicine, published on March 5, 2021 as doi:10.2967/jnumed.120.259630

\title{
PSMA- and GRPR-targeted PET: Results from 50 Patients with Biochemically Recurrent Prostate Cancer
}

Lucia Baratto ${ }^{1}$, Hong Song ${ }^{1}$, Heying Duan ${ }^{1}$, Negin Hatami ${ }^{1}$, Hilary P. Bagshaw ${ }^{2}$, Mark Buyyounouski², Steven Hancock ${ }^{2}$, Sumit Shah ${ }^{3}$, Sandy Srinivas ${ }^{3}$, Patrick Swift², Farshad Moradi $^{1}$, Guido Davidzon ${ }^{1}$, Andrei lagaru ${ }^{1}$

1 Department of Radiology, Division of Nuclear Medicine and Molecular Imaging, Stanford University, Stanford, CA

${ }^{2}$ Department of Radiation Oncology, Stanford University, Stanford, CA

${ }^{3}$ Department of Medicine, Division of Oncology, Stanford University, Stanford, CA

\section{First author:}

Lucia Baratto, MD

Department of Radiology, Division of Nuclear Medicine and Molecular Imaging Stanford University

300 Pasteur Drive, H2200

Stanford, CA 94305

Phone: +1 6507254711

Fax: +16504985047

Ibaratto@stanford.edu

\section{Corresponding author:}

Andrei lagaru, MD

Department of Radiology, Division of Nuclear Medicine and Molecular Imaging Stanford University 
300 Pasteur Drive, $\mathrm{H} 2200$

Stanford, CA 94305

Phone: +1 6507254711

Fax: +16504985047

aiagaru@stanford.edu

Word count: 4979

Running title: PSMA and GRPR PET in Prostate Cancer

Clinicaltrials.gov Identifier: NCT $02624518\left({ }^{68} \mathrm{Ga}-\mathrm{RM} 2\right)$, NCT02673151 ( $\left.{ }^{68} \mathrm{Ga}-\mathrm{PSMA} 11\right)$ and NCT03501940 ( $\left.{ }^{18} \mathrm{~F}-\mathrm{DCFPyL}\right)$ 


\section{Abstract:}

Rationale: Novel radiopharmaceuticals for positron emission tomography (PET) are evaluated for the diagnosis of biochemically recurrent prostate cancer (BCR PC). Here, we compare the gastrin releasing peptide receptors (GRPR) - targeting ${ }^{68} \mathrm{Ga}-\mathrm{RM} 2$ with the prostate specific membrane antigen (PSMA) - targeting ${ }^{68} \mathrm{Ga}-\mathrm{PSMA} 11$ and ${ }^{18} \mathrm{~F}-\mathrm{DCFPyL}$.

Methods: Fifty patients had both ${ }^{68} \mathrm{Ga}-\mathrm{RM} 2 \mathrm{PET} / \mathrm{MRI}$ and ${ }^{68} \mathrm{Ga}-\mathrm{PSMA} 11 \mathrm{PET} / \mathrm{CT}(n=23)$ or ${ }^{18} \mathrm{~F}-$ DCFPyL PET/CT $(n=27)$ at an interval ranging from 1 to 60 days (mean \pm SD: 15.8 \pm 17.7 ). Maximum standardized uptake values $\left(S U V_{\max }\right)$ were collected for all lesions.

Results: RM2 PET was positive in 35 and negative in 15 of the 50 patients. PSMA PET was positive in 37 and negative in 13 of the 50 patients. Both scans detected 70 lesions in 32 patients. Forty-three lesions in 18 patients were identified only on one scan: ${ }^{68} \mathrm{Ga}-\mathrm{RM} 2$ detected 7 more lesions in 4 patients, while PSMA detected 36 more lesions in 13 patients.

Conclusions: ${ }^{68} \mathrm{Ga}-\mathrm{RM} 2$ remains a valuable radiopharmaceutical even when compared with the more widely used ${ }^{68} \mathrm{Ga}-\mathrm{PSMA} 11 /{ }^{18} \mathrm{~F}-\mathrm{DCFPyL}$ in the evaluation of BCR PC. Larger studies are needed to verify that identifying patients for whom these two classes of radiopharmaceuticals are complementary may ultimately allow for personalized medicine.

Key words: ${ }^{68} \mathrm{Ga}-\mathrm{RM} 2 ;{ }^{68} \mathrm{Ga}-\mathrm{PSMA} 11 ;{ }^{18} \mathrm{~F}-\mathrm{DCFPyL}$; PET; prostate cancer 


\section{INTRODUCTION}

Prostate cancer (PC) is the most-common non-cutaneous cancer diagnosed in the United States, accounting for an estimated 191,930 new cases and 33,330 deaths (second only after lung cancer) in 2020 (1). Biochemical recurrence (BCR) within 10 years after primary treatment occurs in $20-40 \%$ of cases after radical prostatectomy and $30-50 \%$ of cases after radiation therapy $(2,3)$. Despite lack of consensus, the prostate-specific antigen (PSA) remains the biomarker of disease after primary treatment. BCR is characterized by heterogeneity; therefore, a single biological target is unlikely to allow for complete understanding and accurate treatment.

Prostate specific membrane antigen (PSMA) is currently the most evaluated positron emission tomography (PET) molecular target for PC (4), showing better sensitivity and specificity than standard imaging for the detection of metastatic disease even at low PSA values (5). Commonly used radiopharmaceuticals targeting PSMA include ${ }^{68} \mathrm{Ga}-\mathrm{PSMA}-\mathrm{HBED}-\mathrm{CC}\left({ }^{68} \mathrm{Ga}-\right.$ PSMA11) (6) and ${ }^{18}$ F-DCFPyL (7). Another class of radiopharmaceuticals used for the assessment of PC patients are the gastrin releasing peptide (GRP) analogs. Among them, ${ }^{68} \mathrm{Ga}-$ BAY86-7548 (RM2) has been reported in clinical studies $(8,9)$. Our group showed a higher ${ }^{68} \mathrm{Ga}-$ RM2 PET detection rate for PC when compared to magnetic resonance imaging (MRI) in a cohort of 32 patients (9).

Here, we compared ${ }^{68} \mathrm{Ga}-\mathrm{RM} 2$ to ${ }^{68} \mathrm{Ga}-\mathrm{PSMA} 11$ and ${ }^{18} \mathrm{~F}-\mathrm{DCFP} y \mathrm{~L}$. In the age of personalized medicine and theragnostics, it is important to identify which patients will benefit from one class of radiopharmaceutical or the other. This cohort was not previously reported.

\section{MATERIALS AND METHODS}

\section{Patient Population}

Participants with suspected BCR PC after primary treatment were prospectively enrolled in 3 clinical trials evaluating the performance of ${ }^{68} \mathrm{Ga}-\mathrm{RM} 2$ (NCT 02624518), ${ }^{68} \mathrm{Ga}-\mathrm{PSMA} 11$ (NCT02673151) and ${ }^{18}$ F-DCFPyL (NCT03501940). Twenty-three patients had both ${ }^{68} \mathrm{Ga}-\mathrm{RM} 2$ 
PET/MRI and ${ }^{68} \mathrm{Ga}-\mathrm{PSMA} 11 \mathrm{PET} / \mathrm{CT}$, while another 27 patients had both ${ }^{68} \mathrm{Ga}-\mathrm{RM} 2 \mathrm{PET} / \mathrm{MRI}$ and ${ }^{18} \mathrm{~F}$-DCFPyL PET/CT. BCR was diagnosed after prostatectomy with or without adjuvant radiotherapy at a PSA level of $0.2 \mathrm{ng} / \mathrm{mL}$ or greater, with a second confirmatory PSA level of at least $0.2 \mathrm{ng} / \mathrm{mL}$ (10). For post radiation therapy patients, BCR was diagnosed as rise of PSA measurement of 2 or more $\mathrm{ng} / \mathrm{mL}$ over the nadir (11). All participants signed an informed consent and the protocols were approved by the local institutional review board. Data collected in these 3 trials was retrospectively analyzed for this comparison.

Clinical parameters including stage of disease, Gleason score, PSA nadir, PSA within 30 days of the scan, PSA velocity, primary and subsequent treatments were obtained from the electronic medical records.

\section{Scanning Protocols}

All ${ }^{68} \mathrm{Ga}-\mathrm{PSMA} 11$ and ${ }^{18} \mathrm{~F}-\mathrm{DCFPyL}$ scans were acquired using a silicon photomultiplier (SiPM)-based PET/CT system (Discovery Molecular Insights - DMI, GE Healthcare, Waukesha, WI). The scans were performed according to PSMA PET guidelines (12) and as previously described (7).

All ${ }^{68} \mathrm{Ga}-\mathrm{RM} 2$ scans were acquired using a time-of-flight enabled simultaneous PET/MRI scanner (SIGNA, GE Heatlhcare), as previously described (9).

The choice of PET/CT or PET/MRI was dictated by the funding available to support the clinical trials. The PET/CT and PET/MRI use the same SiPM-based detectors and we previously reported their clinical evaluation $(13,14)$.

\section{Image Analysis}

Two Nuclear Medicine physicians (AI and LB) reviewed and analyzed all images using MIMvista version 6.9.2 (MIMvista Corp, Cleveland, OH, USA). LB subsequently recorded semiquantitative measurements (maximum standardized uptake values - SUV $V_{\max }$ ). All areas of 
increased radiotracer uptake in sites not expected to show physiological accumulation were reported as "abnormal". Increased uptake was defined as focal tracer uptake higher than adjacent background. ${ }^{68} \mathrm{Ga}-\mathrm{RM} 2$ uptake was considered as physiological in the following tissues: gastrointestinal tract, liver, spleen, pancreas, kidneys, ureters, bladder (15). This approach is similar to guidelines for standard image interpretation for ${ }^{68} \mathrm{Ga}-\mathrm{PSMA} 11$ PET (16). The PETedge tool was used for evaluation of focal uptake outside the expected biodistribution. The diameter of anatomical structures corresponding to focal uptake were measured on T1-weighted MR for ${ }^{68} \mathrm{Ga}-$ RM2 and on CT for ${ }^{68} \mathrm{Ga}-\mathrm{PSMA} 11$ and ${ }^{18} \mathrm{~F}-\mathrm{DCFPyL}$.

The majority of patients with a positive scan $\left({ }^{68} \mathrm{Ga}-\mathrm{RM} 2\right.$ PET/MRI and/or ${ }^{68} \mathrm{Ga}-$ PSMA11/18F-DCFPyL) started therapy after the examination; therefore, follow-up comparison with other imaging modalities was not possible. Pathologic confirmation of the findings was done in 5 participants.

\section{Statistical Analyses}

Statistical analysis was performed with SPSS v26 (SPSS Inc. Chicago, IL). Continuous data are presented as mean \pm standard deviation (SD), minimum-maximum values and frequencies (\%). Welch's test was used to compare PSA and PSA velocity between positive vs negative scans. Paired Wilcoxon signed-rank test was used to compare differences in $S_{U} V_{\max }$ measurements in lesions between the radiopharmaceuticals. Fisher's exact tests was used to correlate clinical parameters with positivity vs negativity of the two radiopharmaceuticals. A $P$ value $<0.05$ was considered significant.

\section{RESULTS}

\section{Patients' Characteristics}

Fifty patients, 52-81 year-old (mean \pm SD: $69.4 \pm 7$ ) had both ${ }^{68} \mathrm{Ga}-\mathrm{RM} 2 \mathrm{PET} / \mathrm{MRI}$ and ${ }^{68} \mathrm{Ga}-$ PSMA11 PET/CT $(n=23)$ or ${ }^{18} \mathrm{~F}-\mathrm{DCFPyL}$ PET/CT $(n=27)$. Thirty-six of the 50 had radical 
prostatectomy as primary treatment and 14 had radiation therapy. Fifteen patients were treated with androgen deprivation therapy before the scans, while 23 started androgen deprivation therapy after the scans. PSA at the time of the scans ranged from 0.1 to $21.5 \mathrm{ng} / \mathrm{mL}$ (mean $\pm S D$ : 4.2 \pm 5$)$. Tables 1 and 2 summarize clinical and imaging characteristics of this cohort of patients.

The injected dose ranged from 111 to $155.4 \mathrm{MBq}$ (mean $\pm S D$ : $114.3 \pm 7.4$ ) for ${ }^{68} \mathrm{Ga}-\mathrm{RM} 2$, from 129.5 to $199.8 \mathrm{MBq}$ (mean $\pm S D: 151.7 \pm 14.8$ ) for ${ }^{68} \mathrm{Ga}-\mathrm{PSMA} 11$ and from 270.1 to $366.3 \mathrm{MBq}$ (mean $\pm S D: 333 \pm 25.9)$ for ${ }^{18} \mathrm{~F}-\mathrm{DCFPyL}$.

The uptake time ranged from 39 to 100 minutes (mean $\pm S D: 52.7 \pm 11$ ) for ${ }^{68} \mathrm{Ga}-\mathrm{RM} 2$ PET/MRI, from 45 to 107.9 minutes (mean \pm SD: $66.3 \pm 15$ ) for ${ }^{68} \mathrm{Ga}-\mathrm{PSMA} 11 \mathrm{PET} / \mathrm{CT}$, and from 60 to 120 minutes (mean \pm SD: $81.2 \pm 17$ ) for ${ }^{18} \mathrm{~F}-\mathrm{DCFPyL}$. The interval between RM2 and PSMA scans ranged from 1 to 60 days (mean $\pm S D$ : $15.8 \pm 17.7$ ).

\section{PSMA ( ${ }^{68}$ Ga-PSMA11 and ${ }^{18}$ F-DCFPyL) vs ${ }^{68}$ Ga-RM2 Findings}

${ }^{68} \mathrm{Ga}-\mathrm{RM} 2 \mathrm{PET}$ was positive in $35(70 \%)$ and negative in $15(30 \%)$ of the 50 patients. PSMA PET was positive in $37(74 \%)$ and negative in $13(26 \%)$ of the 50 patients. Both scans detected 70 lesions in 32 patients, (42 lymph nodes, 7 prostate bed, 6 seminal vesicles, 6 hepatic lesions and 9 bone lesions). SUV $\max$ for these 70 lesions ranged from 1.7 to 52.5 (mean $\pm S D$ : 8.1 \pm 9.4 ) for RM2 and from 1.6 to 79.3 (mean $\pm S D: 16.7 \pm 17.4$ ) for PSMA. The difference in $S U V_{\max }$ was statistically significant $(P<0.001)$.

PSA ranged from 0.3 to $21.5 \mathrm{ng} / \mathrm{mL}$ (mean $\pm S D: 4.4 \pm 4.8$ ) and from 0.1 to $19.2 \mathrm{ng} / \mathrm{mL}$ (mean \pm SD: $3.6 \pm 5.7$ ) for RM2 positive vs. negative scans, respectively and the difference was not significant (NS) $(P=0.775)$. PSA ranged from 0.2 to $21.5 \mathrm{ng} / \mathrm{mL}$ (mean $\pm S D: 4.2 \pm 4.7$ ) and from 0.1 to $19.2 \mathrm{ng} / \mathrm{mL}$ (mean \pm SD: $3.6 \pm 6.1$ ) for PSMA positive vs. negative scans, respectively and the difference was NS $(P=0.739)$.

PSA velocity ranged from 0.1 to $42 \mathrm{ng} / \mathrm{mL} /$ year (mean $\pm S D: 5.7 \pm 9.8$ ) and from 0.1 to 21.3 $\mathrm{ng} / \mathrm{mL} /$ year (mean $\pm \mathrm{SD}: 3.5 \pm 5.5$ ) for RM2 positive vs. negative scans, respectively and the 
difference was NS ( $P=0.320)$. PSA velocity ranged from 0.1 to $42 \mathrm{ng} / \mathrm{mL} /$ year (mean $\pm S D: 5.6 \pm 9.8)$ and from 0.1 to $12.2 \mathrm{ng} / \mathrm{mL} /$ year (mean $\pm S D: 2.9 \pm 3.9$ ) for PSMA positive vs. negative scans, respectively and the difference was NS $(P=0.174)$.

The positivity rate for $\mathrm{PSA} \leq 0.5,>0.5$ to $\leq 1,>1$ to $\leq 2,>2$ to $\leq 5$ and $>5$ was $38 \%(n=3 / 8)$, $90 \%(n=9 / 11), 50 \%(n=4 / 8), 89 \%(n=8 / 9)$ and $79 \%(n=11 / 14)$ for ${ }^{68} \mathrm{Ga}-\mathrm{RM} 2$ and $22 \%(n=2 / 9)$, $91 \%(n=10 / 11), 75 \%(n=6 / 8), 100 \%(n=9 / 9)$ and $77 \%(n=10 / 13)$ for PSMA.

${ }^{68} \mathrm{Ga}-\mathrm{RM} 2$ detected 7 more lesions in 4 patients compared to PSMA (3 lymph nodes, 3 bone lesions and 1 adrenal gland lesion). Average SUV $\max$ of these lesions was 5.8 and $6 / 7$ had a diameter $<1 \mathrm{~cm}$. The mean PSA in these patients was $5 \mathrm{ng} / \mathrm{mL}$ and 3 of them had a negative PSMA scan.

PSMA detected 36 more lesions in 13 patients compared to RM2 (27 lymph nodes, 1 lung nodule, 8 bone metastases). Average SUV $\max$ of these lesions was 14.8 and 23/36 measured $<1$ $\mathrm{cm}$. The mean PSA value of these patients was $4.6 \mathrm{ng} / \mathrm{mL}$ and 5 of them had a negative RM2 scan.

Ten participants had both negative RM2 and PSMA scans. Their PSA at the time of the scans ranged $0.1-19.2 \mathrm{ng} / \mathrm{ml}$ (mean $\pm S D: 3.1 \pm 6.1$ ). This subgroup included 6 participants with PSA $\leq 0.5 \mathrm{ng} / \mathrm{ml}, 2$ participants with PSA of $1.2 \mathrm{ng} / \mathrm{ml}$ and $1.4 \mathrm{ng} / \mathrm{ml}$, respectively, and 2 participants with PSA of $8.2 \mathrm{ng} / \mathrm{ml}$ and $19.2 \mathrm{ng} / \mathrm{ml}$, respectively.

We did not identify any significant correlation between radiological findings (RM2 and PSMA positive vs. negative scans) and clinical parameters such as Gleason score $(\leq 3+4 ; \geq 4+3)$, primary treatment (radical prostatectomy vs radiation therapy) or androgen deprivation therapy before imaging.

Figures 1 and 2 and Supplemental Figures 1 and 2 show pairs of ${ }^{68} \mathrm{Ga}-\mathrm{RM} 2$ and ${ }^{18} \mathrm{~F}-$ DCFPyL findings in different participants. We previously published images comparing ${ }^{68} \mathrm{Ga}-\mathrm{RM} 2$ and ${ }^{68} \mathrm{Ga}-\mathrm{PSMA} 11(8)$.

Lesions analysis for ${ }^{68} \mathrm{Ga}-\mathrm{RM} 2$ vs ${ }^{68} \mathrm{Ga}-\mathrm{PSMA} 11 /{ }^{18} \mathrm{~F}-\mathrm{DCFP} y \mathrm{~L}$ is shown in Table 3. 


\section{DISCUSSION}

Our study evaluated GRPR and PSMA PET radiopharmaceuticals in patients with BCR PC. The ${ }^{68} \mathrm{Ga}-\mathrm{RM} 2$ positivity rate is similar to our prior published reports $(8,9)$. The overall semiquantitative analysis showed that PSMA radiopharmaceuticals had higher SUV $\mathrm{max}_{\text {measurements }}$ than RM2, and the difference was statistically significant. However, there were differences between ${ }^{68} \mathrm{Ga}-\mathrm{PSMA} 11$ and ${ }^{18} \mathrm{~F}-\mathrm{DCFPyL}$ measurements against ${ }^{68} \mathrm{Ga}-\mathrm{RM} 2$, with higher and statistically significant values only for ${ }^{18} \mathrm{~F}-\mathrm{DCFPyL}$. This may be due to differences between ${ }^{68} \mathrm{Ga}$ and ${ }^{18} \mathrm{~F}$ labeled radiopharmaceuticals. Prior work by Dietlein et al. showed that same lesions have higher uptake measured on ${ }^{18} \mathrm{~F}-\mathrm{DCFP} y \mathrm{~L}$ than on ${ }^{68} \mathrm{Ga}-\mathrm{PSMA} 11$ PET (17). PSA velocity for patients with positive vs. negative scans was not statistically significant for either GRPR or PSMA PET in this cohort.

We previously reported the first comparson of ${ }^{68} \mathrm{Ga}-\mathrm{RM} 2$ and ${ }^{68} \mathrm{Ga}-\mathrm{PSMA} 11$ in a small pilot study (8). Here we expanded with a new cohort of patients and two different PSMA targeting radiopharmaceuticals. Hoberuck et al reported data from 16 patients with mostly advanced PC who underwent both ${ }^{68} \mathrm{Ga}-\mathrm{PSMA} 11 \mathrm{PET} / \mathrm{CT}$ or ${ }^{68} \mathrm{Ga}-\mathrm{PSMA} 11 \mathrm{PET} / \mathrm{MRI}$ and ${ }^{68} \mathrm{Ga}-\mathrm{RM} 2 \mathrm{PET} / \mathrm{CT}$ (18). ${ }^{68} \mathrm{Ga}-\mathrm{RM} 2 \mathrm{PET} / \mathrm{CT}$ showed two osseous lesions not seen by ${ }^{68} \mathrm{Ga}-\mathrm{PSMA} 11$, while the latter showed avid uptake in several locations not visible with ${ }^{68} \mathrm{Ga}-\mathrm{RM} 2$. No previous studies compared ${ }^{18}$ F-DCFPyL and ${ }^{68} \mathrm{Ga}-\mathrm{RM} 2$.

PSMA ligands have high positivity rate even at low PSA values (5). One study showed $50 \%$ positivity when PSA $<0.5 \mathrm{ng} / \mathrm{mL}$ in a cohort of 319 participants (19). In our cohort, the positivity rate was similar for PSMA and RM2 (2/9 and 3/8, respectively) at PSA $<0.5 \mathrm{ng} / \mathrm{mL}$. Larger studies are needed to confirm these preliminary observations.

GRPR are not highly expressed in advanced states of androgen-independent PC, especially in osseous metastases (20). Here, ${ }^{68} \mathrm{Ga}-\mathrm{RM} 2$ identified 3 bone lesions in 1 patient that were not conspicuous on PSMA. This patient was previously treated with radical prostatectomy and ADT, subsequently becoming androgen-independent. On the other hand, ${ }^{68} \mathrm{Ga}-\mathrm{RM} 2 \mathrm{PET}$ did 
not identify 8 osseous lesions seen by PSMA in other patients. These findings require further evaluation.

Some of the patients in this cohort had ADT before the scans and this may have influenced the uptake of the two radiopharmaceuticals. PSMA uptake is regulated by androgen hormones and ADT may considerably increase PSMA-ligand uptake (21-23). A single study suggests that ADT induces GRP activity, activation of NF-KB and increased levels of AR-V7 expression resulting in progression to CRPC (24).

Recently, interest in metastasis directed therapies in patients with minimal metastatic tumor burden ("oligometastatic disease") has increased (25); in these patients, for whom the exact number and localization of the lesions is of great importance, having access to different classes of radiopharmaceuticals may be very useful. Whether the PSA rise reflects a loco-regional recurrence or distant metastatic disease still remain an important question in BCR PC, because treatment planning would change accordingly from a potentially curative local therapy to watchful waiting or palliative systemic treatment. In this setting and considering how heterogeneous PC is, identifying patients for whom different classes of radiopharmaceuticals are complementary may ultimately allow for personalized medicine. The use of combination therapies with non-overlapping toxicities may allow delivery of greater doses to lesions, as well as possibly less adverse events.

Our study has limitations including the relatively small number of patients analyzed (albeit the largest dataset of GRPR vs PSMA PET imaging at BCR PC) and the different methods used for scanning patients, dictated by available research funding. However, both PET/CT and PET/MRI used the same SiPM-based detectors that provide similar performance in both modalities. MRAC is not ideal for the skeleton; it is known that improperly accounting for bone may lead to underestimation of PET signal in tissues near bone (26) and this may have impacted the results of ${ }^{68} \mathrm{Ga}-\mathrm{RM} 2$. Lastly, pathology confirmation of the identified lesions was limited to a small number of participants $(10 \%)$ due to a bias from the referring physicians who accepted 
putative sites of disease on imaging after initial biopsies returned no false positive ${ }^{68} \mathrm{Ga}-\mathrm{RM} 2$ findings; in addition, PSMA findings are now widely accepted by treating physicians.

In an attempt to find correlation between clinical features and GRPR vs. PSMA positive or negative lesions we ran Fisher's exact test but did not observe any significant associations. This may be due to the small cohort of patients enrolled. Furthermore, $20 \%$ of our participants had negative PSMA and RM2 scans, including at PSA $>5 \mathrm{ng} / \mathrm{ml}$. These underline the complexity of the PC biology and should be evaluated in larger prospective studies.

\section{CONCLUSIONS}

${ }^{68} \mathrm{Ga}-\mathrm{RM} 2$ remains a valuable radiopharmaceutical even when compared with the more widely used ${ }^{18} \mathrm{~F}-\mathrm{DCFPyL} /{ }^{68} \mathrm{Ga}-\mathrm{PSMA} 11$ in the evaluation of BCR PC. Larger studies are needed to verify that identifying patients for whom these two classes of radiopharmaceuticals are complementary may ultimately allow for personalized medicine.

\section{DISCLOSURE}

NCT $02624518\left({ }^{68} \mathrm{Ga}-\mathrm{RM} 2\right)$ was supported by Department of Defense Impact Award (W81XWH16-1-0604). NCT02673151 ( $\left.{ }^{68} \mathrm{Ga}-\mathrm{PSMA} 11\right)$ was partially supported by institutional support from GE Healthcare and by Department of Radiology discretionary funds. NCT03501940 ( ${ }^{18} \mathrm{~F}$ DCFPyL) was partially supported by Department of Radiology discretionary funds. Life MI provided the RM2 precursor. Progenics Pharmaceuticals provided ${ }^{18} \mathrm{~F}-\mathrm{DCFPyL}$ as part of a Research Access Program. No potential conflicts of interest relevant to this article exist. 
KEY POINTS

QUESTION: Is there a benefit to using GRPR PET in addition to PSMA PET in patients with BCR PC?

PERTINENT FINDINGS: 50 participants with BCR PC had both ${ }^{68} \mathrm{Ga}-\mathrm{RM} 2$ and ${ }^{68} \mathrm{Ga}-$

PSMA11/18F-DCFPyL PET. RM2 PET was positive in $35(70 \%)$ and negative in $15(30 \%)$ of the 50 patients. PSMA PET was positive in $37(74 \%)$ and negative in $13(26 \%)$ of the 50 patients.

Both scans detected 70 lesions in 32 patients, (42 lymph nodes, 7 prostate bed, 6 seminal vesicles, 6 hepatic lesions and 9 bone lesions). Forty-three lesion in 18 patients were seen only by one class of radiopharmaceutical: ${ }^{68} \mathrm{Ga}-\mathrm{RM} 2$ detected 7 more lesions in 4 patients, while PSMA detected 36 more lesions in 14 patients (9 lesions were identified by ${ }^{68} \mathrm{Ga}-\mathrm{PSMA} 11$ and 27 by ${ }^{18}$ F-DCFPyL).

IMPLICATIONS FOR PATIENT CARE: ${ }^{68} \mathrm{Ga}-\mathrm{RM} 2$ remains a valuable radiopharmaceutical even when compared with the more widely used ${ }^{68} \mathrm{Ga}-\mathrm{PSMA} 11 /{ }^{18} \mathrm{~F}-\mathrm{DCFPyL}$ in the evaluation of BCR PC. Larger studies are needed to verify that identifying patients for whom these two classes of radiopharmaceuticals are complementary may ultimately allow for personalized medicine. 


\section{References:}

1. Siegel RL, Miller KD, Jemal A. Cancer statistics, 2020. CA Cancer J Clin. 2020;70:7-30.

2. Roehl KA, Han M, Ramos CG, Antenor JA, Catalona WJ. Cancer progression and survival rates following anatomical radical retropubic prostatectomy in 3,478 consecutive patients: long-term results. J Urol. 2004;172:910-914.

3. Freedland SJ, Humphreys EB, Mangold LA, et al. Risk of prostate cancer-specific mortality following biochemical recurrence after radical prostatectomy. JAMA. 2005;294:433439.

4. De Visschere PJL, Standaert C, Futterer JJ, et al. A Systematic Review on the Role of Imaging in Early Recurrent Prostate Cancer. Eur Urol Oncol. 2019;2:47-76.

5. Maurer T, Eiber M, Schwaiger M, Gschwend JE. Current use of PSMA-PET in prostate cancer management. Nat Rev Urol. 2016;13:226-235.

6. Afshar-Oromieh A, Holland-Letz T, Giesel FL, et al. Diagnostic performance of (68)GaPSMA-11 (HBED-CC) PET/CT in patients with recurrent prostate cancer: evaluation in 1007 patients. Eur J Nucl Med Mol Imaging. 2017;44:1258-1268.

7. Song $\mathrm{H}$, Harrison $\mathrm{C}$, Duan $\mathrm{H}$, et al. Prospective Evaluation of (18)F-DCFPyL PET/CT in Biochemically Recurrent Prostate Cancer in an Academic Center: A Focus on Disease Localization and Changes in Management. J Nucl Med. 2020;61:546-551.

8. Minamimoto R, Hancock S, Schneider B, et al. Pilot Comparison of (6)(8)Ga-RM2 PET and (6)(8)Ga-PSMA-11 PET in Patients with Biochemically Recurrent Prostate Cancer. J Nucl Med. 2016;57:557-562.

9. Minamimoto R, Sonni I, Hancock S, et al. Prospective Evaluation of (68)Ga-RM2 $\mathrm{PET} / \mathrm{MRI}$ in Patients with Biochemical Recurrence of Prostate Cancer and Negative Findings on Conventional Imaging. J Nucl Med. 2018;59:803-808. 
10. Cookson MS, Aus G, Burnett AL, et al. Variation in the definition of biochemical recurrence in patients treated for localized prostate cancer: the American Urological Association Prostate Guidelines for Localized Prostate Cancer Update Panel report and recommendations for a standard in the reporting of surgical outcomes. J Urol. 2007;177:540-545.

11. Roach III M, Hanks G, Thames Jr H, et al. Defining biochemical failure following radiotherapy with or without hormonal therapy in men with clinically localized prostate cancer: recommendations of the RTOG-ASTRO Phoenix Consensus Conference. International Journal of Radiation Oncology* Biology* Physics. 2006;65:965-974.

12. Fendler WP, Eiber M, Beheshti M, et al. (68)Ga-PSMA PET/CT: Joint EANM and SNMMI procedure guideline for prostate cancer imaging: version 1.0. Eur J Nucl Med Mol Imaging. 2017;44:1014-1024.

13. lagaru A, Mittra E, Minamimoto $R$, et al. Simultaneous whole-body time-of-flight 18FFDG PET/MRI: a pilot study comparing SUVmax with PET/CT and assessment of MR image quality. Clin Nucl Med. 2015;40:1-8.

14. Baratto L, Park SY, Hatami N, et al. 18F-FDG silicon photomultiplier PET/CT: A pilot study comparing semi-quantitative measurements with standard PET/CT. PLoS One. 2017;12:e0178936.

15. Baratto L, Duan H, Laudicella R, et al. Physiological (68)Ga-RM2 uptake in patients with biochemically recurrent prostate cancer: an atlas of semi-quantitative measurements. Eur J Nucl Med Mol Imaging. 2020;47:115-122.

16. Fanti S, Minozzi S, Morigi JJ, et al. Development of standardized image interpretation for 68Ga-PSMA PET/CT to detect prostate cancer recurrent lesions. Eur J Nucl Med Mol Imaging. 2017;44:1622-1635.

17. Dietlein M, Kobe C, Kuhnert G, et al. Comparison of [(18)F]DCFPyL and [ (68)Ga]GaPSMA-HBED-CC for PSMA-PET Imaging in Patients with Relapsed Prostate Cancer. Mol Imaging Biol. 2015;17:575-584. 
18. Hoberuck S, Michler E, Wunderlich G, et al. 68Ga-RM2 PET in PSMA- positive and negative prostate cancer patients. Nuklearmedizin. 2019;58:352-362.

19. Afshar-Oromieh A, Malcher A, Eder M, et al. PET imaging with a [68Ga]gallium-labelled PSMA ligand for the diagnosis of prostate cancer: biodistribution in humans and first evaluation of tumour lesions. Eur J Nucl Med Mol Imaging. 2013;40:486-495.

20. Beer M, Montani M, Gerhardt J, et al. Profiling gastrin-releasing peptide receptor in prostate tissues: clinical implications and molecular correlates. Prostate. 2012;72:318-325.

21. Evans MJ, Smith-Jones PM, Wongvipat J, et al. Noninvasive measurement of androgen receptor signaling with a positron-emitting radiopharmaceutical that targets prostate-specific membrane antigen. Proc Natl Acad Sci U S A. 2011;108:9578-9582.

22. Murga JD, Moorji SM, Han AQ, Magargal WW, DiPippo VA, Olson WC. Synergistic cotargeting of prostate-specific membrane antigen and androgen receptor in prostate cancer. Prostate. 2015;75:242-254.

23. Meller B, Bremmer F, Sahlmann CO, et al. Alterations in androgen deprivation enhanced prostate-specific membrane antigen (PSMA) expression in prostate cancer cells as a target for diagnostics and therapy. EJNMMI Res. 2015;5:66.

24. Qiao J, Grabowska MM, Forestier-Roman IS, et al. Activation of GRP/GRP-R signaling contributes to castration-resistant prostate cancer progression. Oncotarget. 2016;7:6195561969.

25. Giannarini G, Fossati N, Gandaglia G, et al. Will Image-guided Metastasis-directed Therapy Change the Treatment Paradigm of Oligorecurrent Prostate Cancer? Eur Urol. 2018;74:131-133.

26. Chen $\mathrm{Y}, \mathrm{An} \mathrm{H}$. Attenuation Correction of PET/MR Imaging. Magn Reson Imaging Clin $N$ Am. 2017;25:245-255. 


\section{FIGURE LEGENDS}

Figure 1: 63 year-old man previously treated with radical prostatectomy, followed by salvage $\mathrm{RT}+\mathrm{ADT}$, presenting with BCR PC (PSA $0.4 \mathrm{ng} / \mathrm{mL}$ and PSA velocity $1.6 \mathrm{ng} / \mathrm{mL} / \mathrm{year}$ ). Maximum intensity projection (MIP) of ${ }^{68} \mathrm{Ga}-\mathrm{RM} 2(\mathrm{~A})$ and ${ }^{18} \mathrm{~F}-\mathrm{DCFPyL}(\mathrm{B})$, axial PET of ${ }^{68} \mathrm{Ga}-\mathrm{RM} 2(\mathrm{C})$ and ${ }^{18} \mathrm{~F}-\mathrm{DCFPyL}(\mathrm{E})$, fused axial PET/MRI of ${ }^{68} \mathrm{Ga}-\mathrm{RM} 2(\mathrm{D})$ and fused axial ${ }^{18} \mathrm{~F}-\mathrm{DCFPyL}$ PET/CT (F) are shown. Red arrows mark left peri-rectal lymph nodes with significantly lower ${ }^{68} \mathrm{Ga}-\mathrm{RM} 2$ uptake than ${ }^{18} \mathrm{~F}$-DCFPyL uptake.

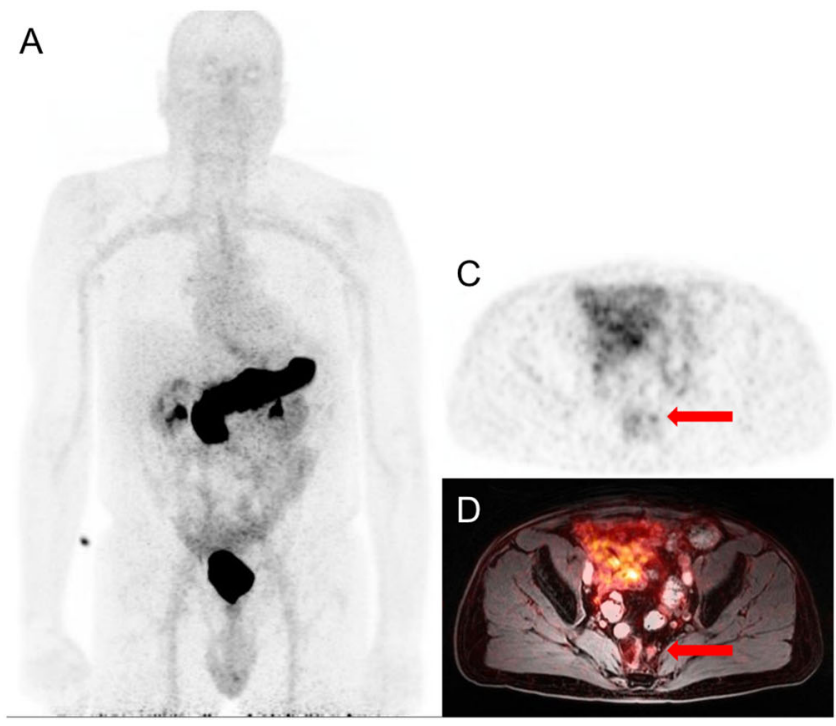

B

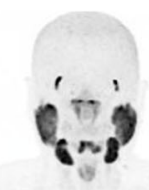

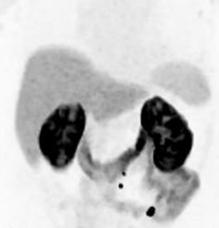

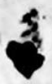

$\mathrm{E}$
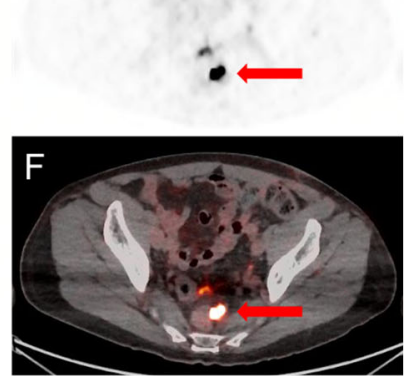
Figure 2: 66 year-old man previously treated with RT+ADT, presenting with BCR PC (PSA 11.6 $\mathrm{ng} / \mathrm{mL}$ and PSA velocity $12.2 \mathrm{ng} / \mathrm{mL} /$ year). MIP of ${ }^{68} \mathrm{Ga}-\mathrm{RM} 2(\mathrm{~A})$ and ${ }^{18} \mathrm{~F}-\mathrm{DCFPyL}(\mathrm{B})$, axial PET of ${ }^{68} \mathrm{Ga}-\mathrm{RM} 2(\mathrm{C})$ and ${ }^{18} \mathrm{~F}-\mathrm{DCFPyL}(\mathrm{E})$, fused axial PET/MRI of ${ }^{68} \mathrm{Ga}-\mathrm{RM} 2(\mathrm{D})$ and fused axial ${ }^{18} \mathrm{~F}-$ DCFPyL PET/CT (F) are shown. Red arrows mark right adrenal lesion clearly seen on ${ }^{68} \mathrm{Ga}-\mathrm{RM} 2$ but not prospectively identified on ${ }^{18} \mathrm{~F}-\mathrm{DCFPyL}$ given similar uptake in the adrenal gland and liver parenchyma. Blue arrows mark physiologic ${ }^{68} \mathrm{Ga}-\mathrm{RM} 2$ uptake in the pancreas.

A

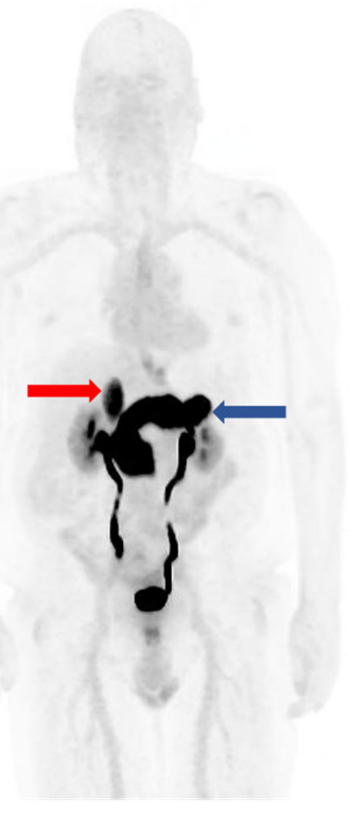

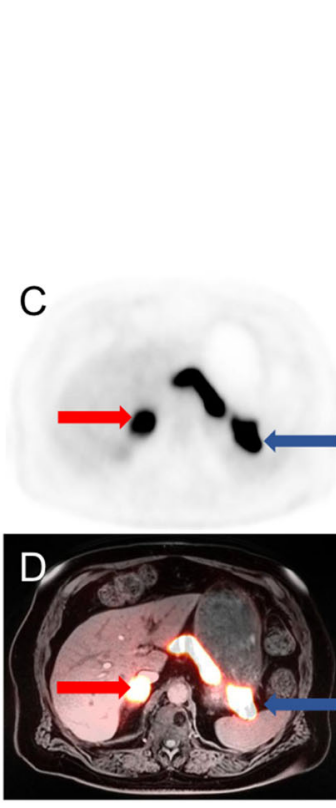

B

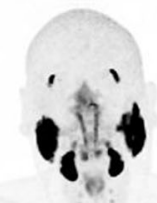

C

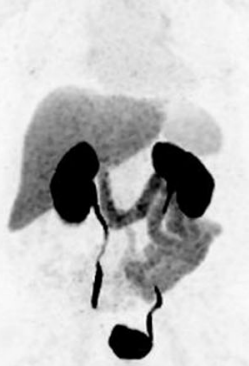

E
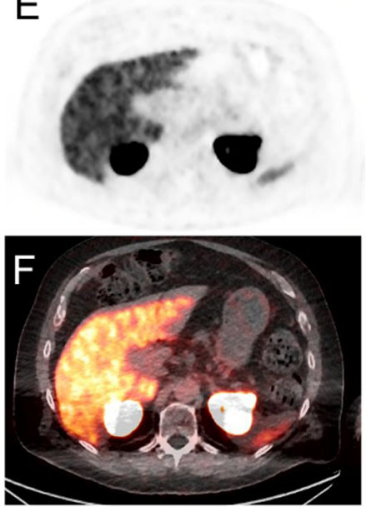
Table 1: ${ }^{68} \mathrm{Ga}-\mathrm{RM} 2$ vs. ${ }^{68} \mathrm{Ga}-\mathrm{PSMA} 11$ - patients characteristics and PET imaging results

\begin{tabular}{|c|c|c|c|c|c|c|c|c|c|c|c|}
\hline Age & TNM & GS $^{*}$ & $\begin{array}{c}\text { Primary } \\
\text { Treatment } \\
\text { (year) }\end{array}$ & $\begin{array}{c}\text { Subsequent } \\
\text { Treatment } \\
\text { (year) }\end{array}$ & $\begin{array}{l}\text { PSA } \\
\text { nadir }\end{array}$ & PSA $^{+}$ & $\begin{array}{c}\text { PSA } \\
\text { Velocity }\end{array}$ & RM2 PET & PSMA11 PET & $\begin{array}{c}\text { Days } \\
\text { between } \\
\text { scans } \\
\text { (days) }\end{array}$ & FU \\
\hline 73 & N/A & $5+3$ & $\mathrm{RP}(2004)$ & $\begin{array}{c}\text { Salvage } \\
\text { RT+ADT } \\
(2006)\end{array}$ & $<0.05$ & 5.8 & 5.7 & $\begin{array}{l}\text { Retroperitoneal } \\
\text { LNs }\end{array}$ & Negative & 12 & ADT \\
\hline 69 & T1NOMO & $3+3$ & $\begin{array}{c}\text { BrachyT } \\
(2003)\end{array}$ & RT (2011) & $<0.05$ & 4.2 & 6.8 & Negative & $\begin{array}{l}\text { Retroperitoneal } \\
\text { LNs }\end{array}$ & 11 & ADT \\
\hline 79 & T3aNOM0 & $3+4$ & $\mathrm{RP}(2011)$ & None & $<0.05$ & 0.8 & 0.3 & Negative & Left pelvic LN & 15 & RT to the LN + ADT \\
\hline 73 & T2bNOMO & $3+3$ & $\begin{array}{l}\text { BrachyT } \\
(2015)\end{array}$ & None & $<0.05$ & 7.9 & 3.3 & $\begin{array}{l}\text { Left seminal } \\
\text { vesicle }\end{array}$ & $\begin{array}{l}\text { Left seminal } \\
\text { vesicle }\end{array}$ & 2 & $\begin{array}{l}\text { Brachy } T \text { to the left } \\
\text { prostate and seminal } \\
\text { vesicle } \\
\text { (biopsy proven } \\
\text { recurrence) }\end{array}$ \\
\hline 64 & T2NXM0 & $3+4$ & $\mathrm{RP}(2011)$ & None & & 0.2 & 0.1 & Negative & Negative & 9 & $\mathrm{~N} / \mathrm{A}$ \\
\hline 68 & T3aNOM0 & $3+4$ & $\mathrm{RP}(2016)$ & None & $<0.05$ & 0.3 & 0.2 & Left pelvic LNs & Negative & 9 & RT to the pelvis +ADT \\
\hline 74 & T1cNXM0 & $4+3$ & $\begin{array}{l}\text { BrachyT } \\
(2007)\end{array}$ & None & $\mathrm{N} / \mathrm{A}$ & 5.8 & 2.5 & $\begin{array}{l}\text { Left prostate } \\
\text { bed }\end{array}$ & $\begin{array}{l}\text { Left prostate } \\
\text { bed, right } 3 r^{d} \\
\text { rib }\end{array}$ & 6 & $\begin{array}{l}\text { BrachyT to the prostate } \\
\text { bed (biopsy proven } \\
\text { recurrence) + SBRT to } \\
\text { the } 3 \mathrm{~d} \text { right rib }\end{array}$ \\
\hline 73 & T3aNOMO & $3+4$ & $\mathrm{RP}(2003)$ & None & $<1$ & 10.6 & 39.9 & Left pelvic mass & $\begin{array}{c}\text { Right prostate } \\
\text { bed, left pelvic } \\
\text { mass, } \\
\text { retroperitoneal } \\
\text { LNs }\end{array}$ & 18 & $\begin{array}{l}\mathrm{RT} \text { to the pelvis and } \\
\text { para-aortic } \mathrm{LNs}+\mathrm{ADT}\end{array}$ \\
\hline 66 & T3aNOMO & $4+3$ & $\mathrm{RP}(2017)$ & None & $<0.05$ & 0.7 & 5.7 & $\begin{array}{l}\text { Right pelvic } \\
\text { LNs, right femur }\end{array}$ & $\begin{array}{l}\text { Right pelvic } \\
\text { LNs, right } \\
\text { femur }\end{array}$ & 1 & $\begin{array}{l}\text { RT to the pelvis and } \\
\text { prostate bed +ADT }\end{array}$ \\
\hline 66 & T2cNOMx & $3+4$ & $\mathrm{RP}(2011)$ & $\begin{array}{c}\text { Salvage } \\
\text { RT+ADT } \\
(2011)\end{array}$ & $\mathrm{N} / \mathrm{A}$ & 8.2 & 14.4 & Negative & Negative & 1 & ADT \\
\hline 62 & T3aN1M0 & $4+3$ & RP (2017) & None & $<0.05$ & 0.4 & 1.2 & B/L Pelvic LNs & B/L Pelvic LNs & 43 & $\begin{array}{l}\text { RT to the Pelvis and } \\
\text { Prostate Bed +ADT }\end{array}$ \\
\hline 70 & T3cNOMO & $4+3$ & $\mathrm{RP}(2001)$ & $\begin{array}{c}\text { Salvage } \\
\text { RT+ADT } \\
(2008)\end{array}$ & $<0.05$ & 1.8 & 0.6 & $\begin{array}{l}\text { Retroperitoneal } \\
\text { LNs }\end{array}$ & $\begin{array}{l}\text { Retroperitoneal } \\
\text { LNs }\end{array}$ & 2 & ADT \\
\hline 72 & T3NOMx & $3+4$ & RP (2005) & None & $\mathrm{N} / \mathrm{A}$ & 0.7 & 0.4 & $\begin{array}{c}\text { Right prostate } \\
\text { bed }\end{array}$ & $\begin{array}{c}\text { Right prostate } \\
\text { bed }\end{array}$ & 7 & $\mathrm{~N} / \mathrm{A}$ \\
\hline 77 & N/A & $4+4$ & $\begin{array}{l}\mathrm{RT}+\mathrm{ADT} \\
(2001)\end{array}$ & ADT & $\mathrm{N} / \mathrm{A}$ & 54 & 21.5 & $\begin{array}{c}\text { Retroperitoneal } \\
\text { LNs, left } \\
\text { supraclavicular } \\
\text { LNs } \\
\end{array}$ & $\begin{array}{c}\text { Retroperitoneal } \\
\text { LNs, left } \\
\text { supraclavicular } \\
\text { LNs } \\
\end{array}$ & 7 & ADT \\
\hline 71 & T1cNOM0 & $3+3$ & RP (2013) & $\begin{array}{c}\text { Salvage RT } \\
\text { (2014) }\end{array}$ & 0.7 & 62 & 3.1 & $\begin{array}{c}\text { Retroperitoneal } \\
\text { LNs }\end{array}$ & $\begin{array}{c}\text { Retroperitoneal } \\
\text { LNs }\end{array}$ & 5 & ADT \\
\hline 60 & T2cNOMO & $3+4$ & RP (2011) & $\begin{array}{c}\text { Bachy } T+A D T \\
(2013)\end{array}$ & $<0.05$ & 56.4 & 1.9 & $\begin{array}{l}\text { Left pelvic } \\
\text { nodule }\end{array}$ & $\begin{array}{l}\text { Left pelvic } \\
\text { nodule }\end{array}$ & 3 & $\begin{array}{l}\text { RT to the left pelvic } \\
\text { nodule }\end{array}$ \\
\hline 71 & T4NOMO & $4+5$ & $\begin{array}{c}\mathrm{RT}+\mathrm{ADT} \\
(2014)\end{array}$ & None & 0.1 & 1.5 & 1.9 & $\begin{array}{c}\text { Right prostate } \\
\text { bed }\end{array}$ & $\begin{array}{l}\text { Right prostate } \\
\text { bed }\end{array}$ & 2 & $\begin{array}{l}\text { HIFU to the } \\
\text { prostate+ADT } \\
\text { (biopsy proven } \\
\text { recurrence) }\end{array}$ \\
\hline 63 & T2bNOM0 & $3+4$ & $\mathrm{RP}(2017)$ & None & $<0.05$ & 0.2 & 0.6 & Negative & Negative & 14 & Salvage RT \\
\hline 78 & T3aNOMO & $4+3$ & $\mathrm{RP}(2009)$ & None & 0.15 & 4.3 & 3.5 & B/L pelvic LNs & B/L pelvic LNs & 11 & N/A \\
\hline 79 & T3bNOMO & $5+4$ & $\mathrm{RP}(2012)$ & $\begin{array}{c}\text { Salvage } \\
\text { RT+ADT } \\
(2013)\end{array}$ & $<0.05$ & 1.7 & 3.4 & Negative & Lung nodule & 25 & ADT \\
\hline 67 & T2cNOM0 & $3+4$ & RP $(2017$ & None & $<0.05$ & 1.2 & 1.7 & Negative & Negative & 1 & Salvage RT \\
\hline 74 & T3bNOMO & $4+4$ & $\mathrm{RP}(2011)$ & $\begin{array}{c}\text { Salvage } \\
\text { RT+ADT+ } \\
\text { SBRT }(2011)\end{array}$ & $\mathrm{N} / \mathrm{A}$ & 1 & 2.1 & $\begin{array}{l}\mathrm{B} / \mathrm{L} \text { hilar and } \\
\text { subcarinal LNs }\end{array}$ & $\begin{array}{l}\text { B/L hilar and } \\
\text { subcarinal LNs }\end{array}$ & 19 & ADT \\
\hline
\end{tabular}

GS: Gleason score; RP: radical prostatectomy; RT: radiation therapy; ADT: androgen deprivation therapy; BrachyT: brachytherapy; LN(s):

Lymph node(s); SBRT: stereotactic body radiation therapy; B/L: bilateral;

HIFU: high Intensity focused ultrasound; MET(s): metastasis/metastases; CR: castration resistant; VMAT: volumetric arc therapy

${ }^{+}:$at the time of RM2 and PSMA11 scan;

*: at the time of primary treatment

N/A: not available (patients self-referred from outside our healthcare system were only required to provide documentation for inclusion/exclusion criteria; therefore, some clinical data was not available) 
Table 2: ${ }^{68} \mathrm{Ga}-\mathrm{RM} 2$ vs. ${ }^{18} \mathrm{~F}-\mathrm{DCFPyL}$ - patients characteristics and PET imaging results

\begin{tabular}{|c|c|c|c|c|c|c|c|c|c|c|c|}
\hline Age & TNM/Stage* & GS $^{*}$ & $\begin{array}{l}\text { Primary } \\
\text { Treatment } \\
\text { (year) }\end{array}$ & $\begin{array}{l}\text { Subsequent } \\
\text { Treatment } \\
\text { (year) }\end{array}$ & $\begin{array}{l}\text { PSA } \\
\text { nadir }\end{array}$ & $\mathrm{PSA}^{+}$ & $\begin{array}{c}\text { PSA } \\
\text { Velocity }\end{array}$ & RM2 PET & DCFPYL PET & $\begin{array}{c}\text { Days } \\
\text { between } \\
\text { scans } \\
\text { (days) }\end{array}$ & FU \\
\hline 74 & T2cNOMO & $3+4$ & $\begin{array}{c}\text { VMAT+ } \\
\text { ADT (2011) }\end{array}$ & $\begin{array}{c}\text { Salvage RT } \\
(2016)\end{array}$ & $<0.05$ & 12.5 & 5.2 & $\begin{array}{l}\text { Rt seminal vesicle } \\
\text { and pelvic mass }\end{array}$ & $\begin{array}{l}\text { Rt seminal vesicle } \\
\text { and pelvic mass }\end{array}$ & 8 & ADT \\
\hline 62 & N/A & $4+4$ & $\mathrm{RP}(2012)$ & None & $<0.05$ & 0.2 & 0.1 & Negative & Negative & 18 & Salvage RT \\
\hline 73 & T3bNOMO & $4+5$ & RP (2014) & $\begin{array}{c}\text { Salvage RT } \\
(2015) \\
\end{array}$ & 0.08 & 1.8 & 0.4 & Seminal vesicles & Seminal vesicles & 6 & N/A \\
\hline 77 & T2aNOMO & $4+4$ & $\begin{array}{c}\text { RT+ADT } \\
(2012) \\
\end{array}$ & None & $<0.05$ & 13.4 & 21.3 & Negative & Bone METs & 1 & ADT \\
\hline 59 & T3 & $3+4$ & RT (2012) & None & $<0.05$ & 5.1 & 1 & Right seminal vesicle & Right seminal vesicle & 1 & N/A \\
\hline 78 & T3bNOMO & $4+3$ & RP (2016) & $\begin{array}{c}\text { Salvage } \\
\text { RT+ADT } \\
(2016)\end{array}$ & 1 & 0.9 & 1 & Sternum & Sternum $^{++}$ & 35 & $\begin{array}{c}\mathrm{RT} \text { to the } \\
\text { Sternum+ADT }\end{array}$ \\
\hline 63 & T3bN1M0 & $5+4$ & $\mathrm{RP}(2015)$ & $\begin{array}{c}\text { Salvage } \\
\text { RT+ADT } \\
(2015)\end{array}$ & $<0.05$ & 0.4 & 1.6 & Pelvic LNs & $\begin{array}{l}\text { Pelvic } \mathrm{LNs}^{++} \text {, left iliac } \\
\text { LN }\end{array}$ & 22 & ADT \\
\hline 68 & T3aNOMO & $4+4$ & RP (2018) & $\begin{array}{c}\text { Salvage RT } \\
(2018) \\
\end{array}$ & $N / A$ & 4 & 2.8 & Right pelvic LNs & Right pelvic LNs & 32 & ADT \\
\hline 69 & T3aNOMO & $4+4$ & RP (2015) & $\begin{array}{l}\text { Salvage RT } \\
(2016)\end{array}$ & $\mathrm{N} / \mathrm{A}$ & 9.8 & 7.4 & $\begin{array}{l}\text { Liver capsule, } \\
\text { retroperitoneal LNs }{ }^{++}\end{array}$ & $\begin{array}{l}\text { Liver capsule, } \\
\text { retroperitoneal LNs }\end{array}$ & 55 & ADT \\
\hline 78 & T3aNOMO & $4+3$ & $\mathrm{RP}(2009)$ & None & 0.15 & 3 & 3.5 & B/L pelvic LNs & B/L pelvic $L N s$ & 16 & N/A \\
\hline 73 & T3aN1M0 & $4+4$ & RP (2013) & $\begin{array}{c}\text { Salvage } \\
\text { RT+ADT } \\
(2014) \\
\end{array}$ & 0.1 & 0.8 & 0.3 & Right pelvic LN & Right pelvic LN & 3 & N/A \\
\hline 76 & T3bNOMX & $4+3$ & RP (2010) & $\begin{array}{c}\text { Salvage } \\
\text { RT+ADT } \\
(2011)\end{array}$ & 5.4 & 4.2 & 5.8 & Multiple bone METs ${ }^{++}$ & Multiple bone METs & 1 & $\begin{array}{c}\text { Docetaxel and } \\
\text { Carboplatin }\end{array}$ \\
\hline 78 & T2cNOMx & $3+4$ & RT (2014) & None & $\mathrm{N} / \mathrm{A}$ & 3.3 & 1.1 & Left prostate bed & Left prostate bed $^{++}$ & 47 & N/A \\
\hline 56 & T3aNOMO & $4+4$ & RP (2014) & $\begin{array}{c}\text { Salvage RT } \\
(2015) \\
\end{array}$ & $<0.05$ & 0.6 & 0.4 & $\begin{array}{c}\text { Retroperitoneal LNs, } \\
\text { right pelvic LNs }\end{array}$ & $\begin{array}{c}\text { Retroperitoneal } \mathrm{LNs}, \\
\text { right pelvic } \mathrm{LNs}^{++}\end{array}$ & 10 & N/A \\
\hline 76 & T2aNOMO & $4+4$ & $\operatorname{RP}(2010)$ & None & 0.1 & 0.5 & 0.1 & Negative & Negative & 54 & $\begin{array}{l}\text { Salvage } \\
\text { RT+ADT }\end{array}$ \\
\hline 69 & T3aNOMO & $4+5$ & RP (2017) & $\begin{array}{l}\text { Salvage RT } \\
(20180\end{array}$ & $<0.05$ & 2.3 & 3.5 & $\begin{array}{c}\text { Multiple bone METs, } \\
\text { retroperitoneal/pelvic } \\
\text { LNs }\end{array}$ & $\begin{array}{c}\text { Multiple bone METs, } \\
\text { retroperitoneal/pelvic } \\
\mathrm{LNs}^{++}\end{array}$ & 1 & ADT \\
\hline 75 & T2cNOMO & $3+3$ & RP (2014) & $\begin{array}{c}\text { Salvage RT } \\
(2017) \\
\end{array}$ & 0.2 & 0.9 & 0.4 & Left seminal vesicle & Left seminal vesicle & 1 & N/A \\
\hline 63 & T3aNOMO & $4+5$ & RP (2017) & $\begin{array}{c}\text { Salvage RT } \\
(2017) \\
\end{array}$ & 0.1 & 1.4 & 0.8 & Negative & Negative & 10 & N/A \\
\hline 81 & T3aNOMO & $3+4$ & $\begin{array}{c}\text { BrachyT+ADT } \\
(2016) \\
\end{array}$ & ADT (2017) & $\mathrm{N} / \mathrm{A}$ & 19.2 & 6.5 & Negative & Negative & 60 & N/A \\
\hline 66 & T1cNOMO & $4+3$ & RT (2013) & None & 0.7 & 6.2 & 4.8 & Mediastinal LNs & Mediastinal LNs & 53 & $\begin{array}{c}\text { Biopsy of } \\
\text { mediastinal LN } \\
\text { was FN } \\
\text { (sample error) }\end{array}$ \\
\hline 54 & T3aNOMO & $4+3$ & RP (2018) & None & 1.8 & 2 & 3.5 & Negative & Pelvic LNs & 46 & $\mathrm{~N} / \mathrm{A}$ \\
\hline 72 & T3bNOMO & $4+5$ & RP (2019) & None & 0.10 & 0.2 & 0.6 & Negative & $\begin{array}{c}\text { Left external iliac LN, } \\
\text { iliac bone }\end{array}$ & 28 & $\begin{array}{l}\text { Salvage } \\
\text { RT+ADT }\end{array}$ \\
\hline 66 & T4NOMO & $4+4$ & $\begin{array}{c}\mathrm{RT}+\mathrm{ADT} \\
(2012)\end{array}$ & None & $\mathrm{N} / \mathrm{A}$ & 11.6 & 12.2 & Right adrenal gland & Negative & 6 & $\begin{array}{c}\mathrm{RT} \text { to the } \\
\text { adrenal gland }\end{array}$ \\
\hline 52 & T2cN1M0 & $4+3$ & $\mathrm{RP}(2017)$ & None & $<0.05$ & 0.1 & 0.2 & Negative & Negative & 49 & $\mathrm{~N} / \mathrm{A}$ \\
\hline 74 & T2cNXMO & $3+4$ & RP (2006) & $\begin{array}{c}\text { Salvage } \\
\text { RT+ADT } \\
(2015)\end{array}$ & 0.08 & 12.9 & 42 & $\begin{array}{l}\text { Left supraclavicular, } \\
\text { retroperitoneal LNs }\end{array}$ & $\begin{array}{l}\text { Left supraclavicular, } \\
\text { retroperitoneal } \mathrm{LNs}^{++}\end{array}$ & 8 & $\begin{array}{c}\text { Biopsy of the } \\
\text { left } \\
\text { supraclavicular } \\
\text { LN was TP }\end{array}$ \\
\hline 67 & $\mathrm{~N} / \mathrm{A}$ & $\mathrm{N} / \mathrm{A}$ & $\begin{array}{c}\text { BrachyT } \\
(2013)\end{array}$ & None & 0.3 & 4.7 & 2.9 & Prostate bed & Prostate bed & 1 & None \\
\hline 66 & T2CNOMO & $4+4$ & $\mathrm{RP}(2010)$ & $\begin{array}{l}\text { Salvage RT+ } \\
\text { ADT (2012) }\end{array}$ & 1.87 & 0.7 & 0.1 & Left pelvic LN & Left pelvic $\mathrm{LN}^{++}$ & 4 & $\mathrm{~N} / \mathrm{A}$ \\
\hline 57 & T2cNOMO & $4+3$ & RP (2016) & None & 0.009 & 0.23 & 0.1 & Left prostate bed & Left prostate bed & 1 & Salvage RT \\
\hline
\end{tabular}

${ }^{+}:$at the time of RM2 and PSMA11 scan; ${ }^{++}$: the uptake was higher compared to the other radiopharmaceutical.

*: at the time of primary treatment.

N/A: not available (patients self-referred from outside our healthcare system were only required to provide documentation for inclusion/exclusion

criteria; therefore, some clinical data was not available) 
Table 3: Analysis of lesions from ${ }^{68} \mathrm{Ga}-\mathrm{RM} 2$ vs. ${ }^{68} \mathrm{Ga}-\mathrm{PSMA} 11 / 1{ }^{18} \mathrm{~F}-\mathrm{DCFPyL}$

\begin{tabular}{|l|c|c|c|c|c|c|}
\hline Radiopharmaceutical & $\begin{array}{c}\text { Local } \\
\text { Recurrence } \\
(\boldsymbol{n})\end{array}$ & $\begin{array}{c}\text { SUV }_{\max } \\
\text { average } \\
\text { (local } \\
\text { recurrence) }\end{array}$ & $\begin{array}{c}\text { Lymph } \\
\text { Nodes } \\
(\boldsymbol{n})\end{array}$ & $\begin{array}{c}\mathbf{S U V}_{\max } \\
\text { average } \\
\text { (nodal } \\
\text { metastases) }\end{array}$ & $\begin{array}{c}\text { Bone } \\
\text { metastases } \\
(\boldsymbol{n})\end{array}$ & $\begin{array}{c}\text { SUV }_{\max } \\
\text { average } \\
\text { (bone } \\
\text { metastases) }\end{array}$ \\
\hline RM2 & 13 & 13.3 & $45^{*}$ & 7.9 & $12^{*}$ & 6.1 \\
\hline PSMA & 13 & 11.6 & $69^{* *}$ & 17.7 & $17^{* *}$ & 14.3 \\
\hline
\end{tabular}

PSMA also identified one lung nodule

RM2 also identified one adrenal gland metastasis

Both PSMA and RM2 also identified 6 hepatic lesions

*3 lymph nodes were not detected by ${ }^{68} \mathrm{Ga}$-PSMA 11; 3 bone lesions were not detected by ${ }^{8} \mathrm{~F}-\mathrm{DCFPyL}$

** 27 lymph nodes were not detected by ${ }^{68} \mathrm{Ga}-\mathrm{RM} 2 ; 8$ bone lesions were not detected by ${ }^{68} \mathrm{Ga}-\mathrm{RM} 2$ 


\section{Graphical abstract}
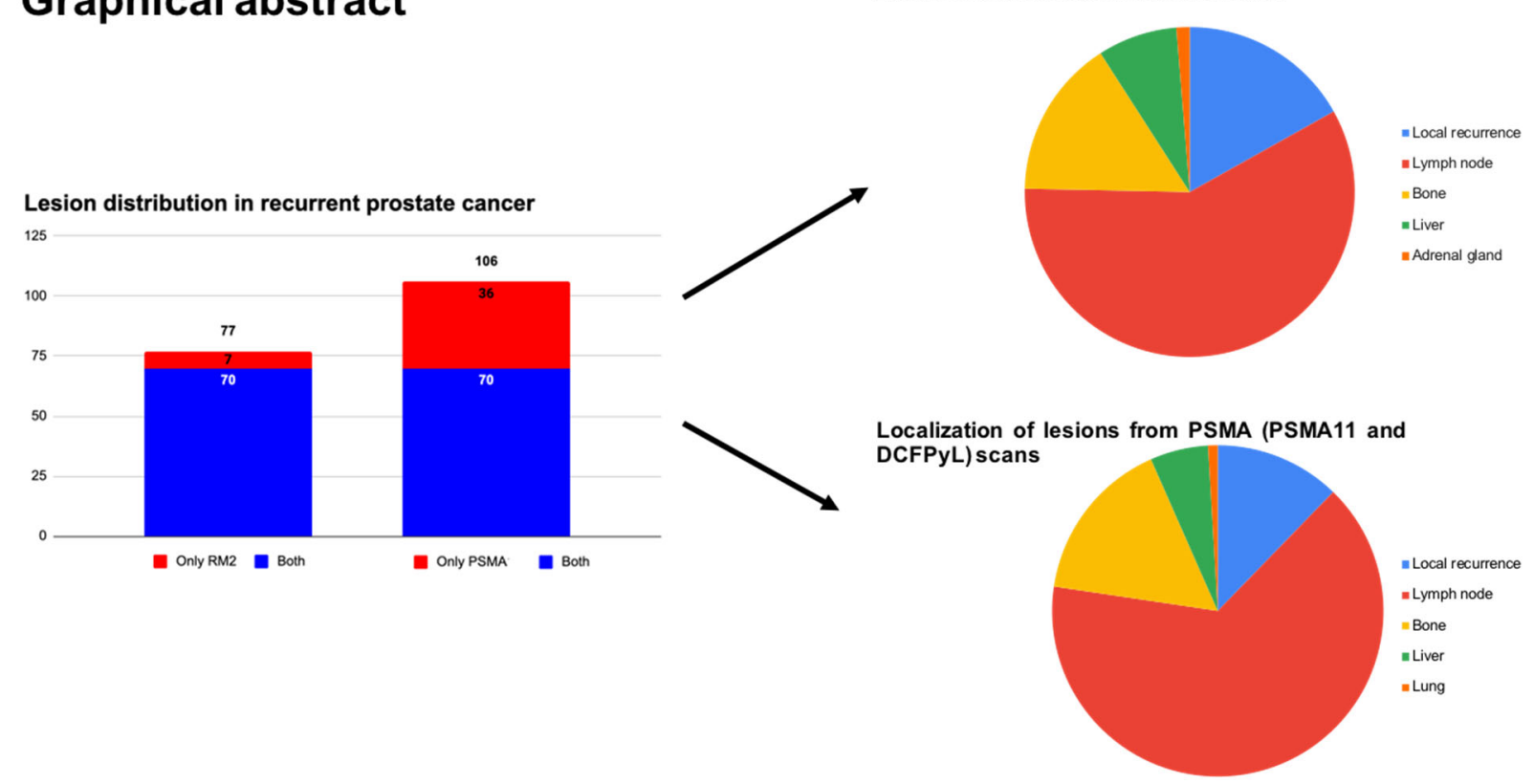

Localization of lesions from RM2 scans 
Supplemental Figure 1: 76 year-old man previously treated with radical prostatectomy, followed by salvage RT+ADT, presenting with BCR PC (PSA $4.2 \mathrm{ng} / \mathrm{mL}$ and PSA velocity $5.8 \mathrm{ng} / \mathrm{mL} / \mathrm{year}$. MIP of ${ }^{68} \mathrm{Ga}-\mathrm{RM} 2(\mathrm{~A})$ and ${ }^{18} \mathrm{~F}$-DCFPyL (D), axial PET of ${ }^{68} \mathrm{Ga}-\mathrm{RM} 2(\mathrm{E}, \mathrm{G})$ and ${ }^{18} \mathrm{~F}$-DCFPyL $(\mathrm{H}, \mathrm{J})$, fused axial PET/MRI of ${ }^{68} \mathrm{Ga}-\mathrm{RM} 2(\mathrm{~B}, \mathrm{~F})$ and fused axial ${ }^{18} \mathrm{~F}$-DCFPyL PET/CT (C, I) are shown. Red arrows mark a lesion in the $\mathrm{T} 7$ vertebra with more intense uptake on ${ }^{68} \mathrm{Ga}-\mathrm{RM} 2$ then on ${ }^{18} \mathrm{~F}-$ DCFPyL PET. Blue arrows mark a lesion in the glenoid process of the right scapula on ${ }^{68} \mathrm{Ga}-\mathrm{RM} 2$, but not on ${ }^{18}$ F-DCFPyL PET.
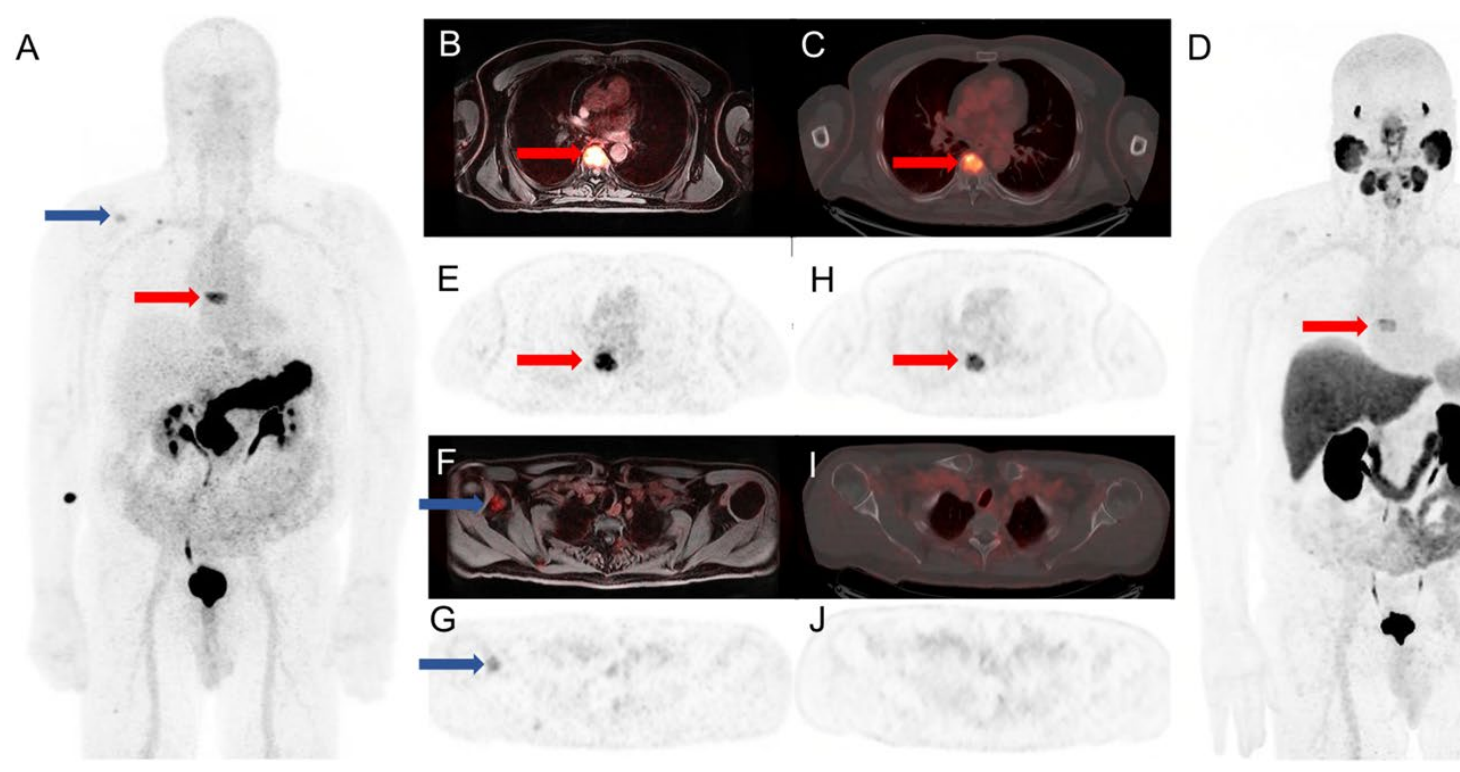

$\mathrm{H}$
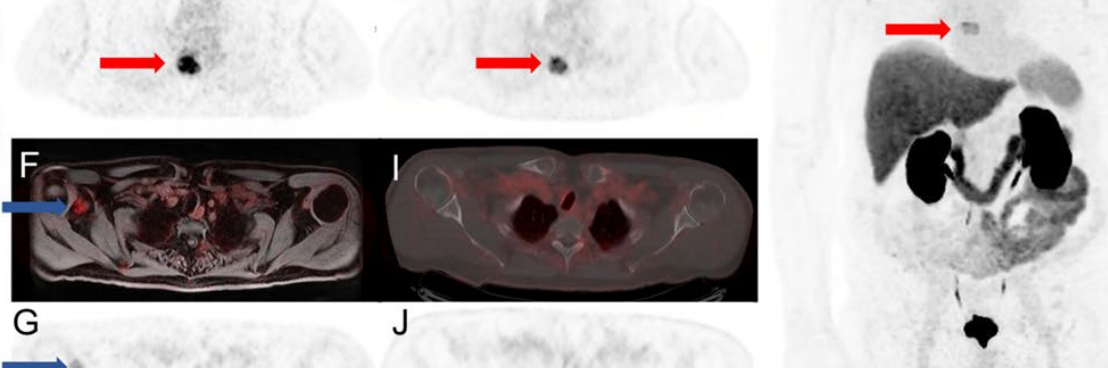
Supplemental Figure 2: 77 year-old man previously treated with RT+ADT, presenting with BCR PC (PSA $13.4 \mathrm{ng} / \mathrm{mL}$ and PSA velocity $21.3 \mathrm{ng} / \mathrm{mL} /$ year). MIP of ${ }^{68} \mathrm{Ga}-\mathrm{RM} 2(\mathrm{~A})$ does not show any of the small bone marrow lesions seen on MIP of ${ }^{18} \mathrm{~F}-\mathrm{DCFPyL}(\mathrm{B})$.

A

B 